\title{
nDalem Prince Joyokusuman's (Gadri Resto) Food Quality: Consumer Response as the Research Approach
}

\author{
Setyo Prasiyono Nugroho \\ \{g4n.tiyo@gmail.com\} \\ Sekolah Tinggi Pariwisata AMPTA Yogyakarta, Indonesia
}

\begin{abstract}
The a This research is aimed to describe the characteristic model of food quality of nDalem Prince Joyokusuman (Gadri Resto) Yogyakarta with consumer response as the research approach. The sample of this research is 101 consumers of nDalem Prince Joyokusuman (Gadri Resto) Yogyakarta. Statistic descriptive method is employed in this research. The variables of this research are color, taste, flavor, presentation, and texture. The data of this research were analyzed by comparing the conclusion of the consumer response with the result of the interview toward chef, cook, and the owner of the restaurant. The result of the analysis shows that overall, of the food quality at $n$ Dalem Prince Joyokusuman (Gadri Resto) can be considered good by the consumers in terms of the color, taste, presentation, flavor and texture with the scale of 4 . Therefore, the consumers feel satisfied with the quality of the food served by nDalem Prince Joyokusuman (Gadri Resto).
\end{abstract}

Keywords: nDalem Prince Joyokusuman's Food, Food Quality, Consumer Response

\section{Introduction}

Industrial sector is a business or activity of processing raw materials or semi-finished goods into finished goods that have added value to get profit. Industrial products are not only in the form of goods, but also in the form of services. For example, in the food and beverage industry there are restaurants, bistros, and cafes. According to Marsum in Nugroho [1] a restaurant is a place or building that is organized commercially, which provides good service to all guests and consumers in the form of food or beverages. nDalem Prince Joyokusuman (Gadri Resto) is one of the restaurants that has the nuances of the Sultan Palace and is also a house which is then also used as a restaurant and museum. The menu served at nDalem Prince Joyokusuman (Gadri Resto) consists of Indonesian and Western food, especially the special cuisine of the Yogyakarta Palace. Various types of special menus of the Yogyakarta Palace served in Gadri Resto are: daging lombok kethok, brongkos ayam asat, gudeg, pandekoek, manuk enom. Meanwhile, the Western menus are wiener schnetzel, fettucinne alfredo, penne carbonara and spaghetti marinara. Nasi Blawong is one of the favorite dishes served in this restaurant. Word d Food quality is very important for restaurant improvement and success. Food quality is the most prominent thing of the overall quality that is given by the restaurant. It is expected to create a positive relationship for customer satisfaction. According to Soriano [2] stated that the quality of food and quality of service are the main attributes that affect customer satisfaction. Food quality has generally been accepted as one of the basic elements 
of the overall consumer experience in restaurants. According to Qin et al. [3], the quality of products in the field of food and beverage has 4 dimensions, they are: freshness, presentation, well cooked, and variety of food. Namkung and Jang [4], stated that if the quality of food provided is satisfying, it will benefit both parties, the restaurant will get a good image and profit in its business, while for customers will get the expected satisfaction. Thus, food quality is one of the best ways to maximize success in the restaurant business. Referring to the explanation above, this study is aimed to present the characteristic model of food quality of nDalem Prince Joyokusuman (Gadri Resto) Yogyakarta with consumer response as a research approach.

\subsection{Food Quality}

In serving food in a good form, we must consider several factors of food quality. According to Fandy Tjiptono and Gregorius Chandra [5], factors that influence product quality are:

a. Color

The color of the food must be combined is such a way so that it does not look pale or inharmonious.

b. Presentation

The dishes have to look satisfying when it is served on the plate.

c. Texture

There are several kinds of dishes texture such as smooth or not, liquid or solid, hard or soft, dry or moist. The level of thin and smooth and shape of food can be felt through the pressure and movement or receptors of the mouth.

d. Taste

The testing point of the tongue is the ability to detected the basic taste: sweet, sour, salty and bitter.

e. Flavor

Flavorist a reaction which affect the consumers before they enjoy of the food. It happens because they are able to smell the food's flavor first.

\subsection{Consumer Responses}

Responses give a major role in shaping behavior. The response to food products often influences the consumer whether they will buy it or not. Positive response will motivate the consumer to buy the product. On the contrary, a negative response will prevent consumers from making a purchase. In the opinion of Louden and Bitta in Nugroho [1] the response is the result of individual activity as a reaction to the stimulus. Stimulus is an attitude in the form of physical, visual, or verbal communication that can affect individual responses [6]. 


\subsection{Framework of Thinking}

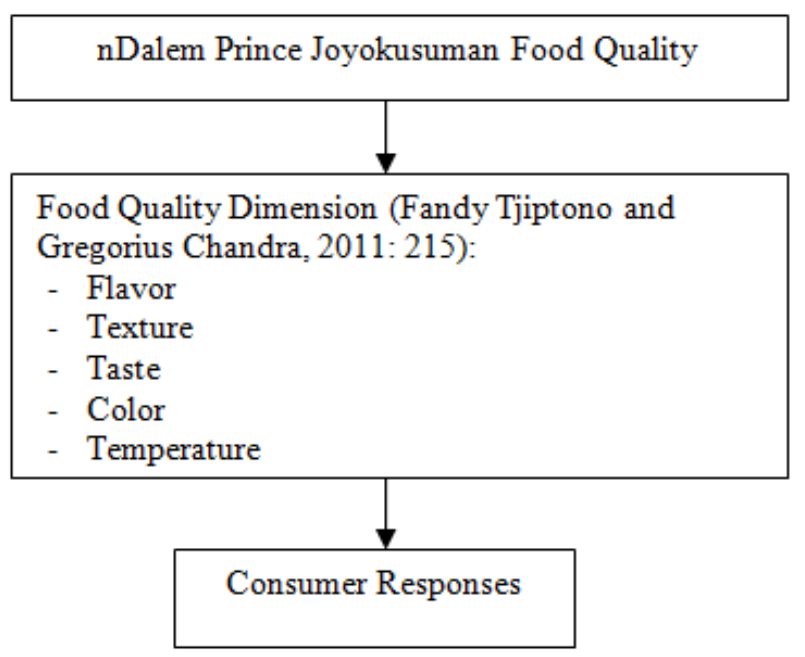

Fig. 1. Framework of Thinking.

\section{Methodology}

The study was conducted in nDalem Prince Joyokusuman (Gadri Resto) located on Jalan Roto Wijayan No. 5 Kraton, Yogyakarta. The study only focused on food quality of nDalem Prince Joyokusuman (consumer response as a research approach). This study used quota sampling technique. The primary data collection method was carried out by a survey method with questionnaire technique. The technique used was Semantics Differential [7]. The analysis was done by using descriptive statistics. It means that this study analyzed the data by describing it without having any intention to make conclusions that are applied to the public. This study analyzes data by discussing conclusions based on consumer responses. It was taken by interviewing the chef, cook, and restaurant owner.

\section{Findings and Discussion}

\subsection{Findings}

Flavor. According to the survey, sixty respondents stated "good" on a scale of 4, where consumers feel satisfied because of the flavor of the food and snacks served to them. It happens because the chef and cook Gadri Resto have done the cooking method correctly in making the food ordered by consumers. 
Table 1. Flavor Single Table

\begin{tabular}{|c|c|c|c|c|c|}
\hline & \multicolumn{5}{|c|}{ Flavor } \\
\hline & $\mathbf{1}$ & $\mathbf{2}$ & $\mathbf{3}$ & $\mathbf{4}$ & $\mathbf{5}$ \\
\hline Total No. & & & $\mathbf{1 1}$ & $\mathbf{6 0}$ & $\mathbf{3 0}$ \\
\hline
\end{tabular}

Color. According to the survey a number of fifty respondents stated "good" on a scale of 4 , where the consumer was satisfied with the color of the food served to them. It can be concluded that the chef and cook of nDalem Prince Joykusuman (Gadri Resto) has done the right thing in the cooking process. They also understand that if food is cooked too long it will change the color because it is over-cooked.

Table 2. Color Single Table

\begin{tabular}{|c|c|c|c|c|c|}
\hline & \multicolumn{5}{|c|}{ Color } \\
\hline & $\mathbf{1}$ & $\mathbf{2}$ & $\mathbf{3}$ & $\mathbf{4}$ & $\mathbf{5}$ \\
\hline Total No. & & & $\mathbf{6}$ & $\mathbf{5 0}$ & $\mathbf{4 5}$ \\
\hline
\end{tabular}

Taste. According to the survey, sixty-six respondents said "good" on a scale of 4 . This proves that the taste of food, snacks, and beverages of nDalem Prince Joyokusuman (Gadri Resto) are satisfying and delicious. It is because the restaurant owner, chef, and all the staff of the chef work together in maintaining recipes that are already exist to maintain the taste of Sultan Palace dishes.

Table 3. Taste Single Table

\begin{tabular}{|c|c|c|c|c|c|}
\hline & \multicolumn{5}{|c|}{ Taste } \\
\hline & $\mathbf{1}$ & $\mathbf{2}$ & $\mathbf{3}$ & $\mathbf{4}$ & $\mathbf{5}$ \\
\hline Total No. & & & & $\mathbf{6 6}$ & \\
\hline
\end{tabular}

Texture. According to a survey of sixty-four respondents said that the texture of the food served to them is "good" on an average scale of 4 . It shows that consumers are satisfied with the texture of the food they eat. Besides, that chefs and cooks understand that to get a perfect texture of food, they have to pay attention to the duration of cooking the food since it is very important.

Table 4. Texture Single Table

\begin{tabular}{|c|c|c|c|c|c|}
\hline & \multicolumn{5}{|c|}{ Texture } \\
\hline & $\mathbf{1}$ & $\mathbf{2}$ & $\mathbf{3}$ & $\mathbf{4}$ & $\mathbf{5}$ \\
\hline Total No. & & & $\mathbf{7}$ & $\mathbf{6 4}$ & $\mathbf{3 0}$ \\
\hline
\end{tabular}

Temperature. According to the survey, a number of fifty respondents said that the temperature of the food served by nDalem Waiter Prince Joyokusuman was "good" the average value on a scale of 4 . It shows that consumers are satisfied with the food they order. In addition, the knowledge of chefs and cooks in handling food temperatures is correct enough. They prioritize guest orders according to the captain order that enters the kitchen. 
Table 5. Temperature Single Table

\begin{tabular}{|c|c|c|c|c|c|}
\hline & \multicolumn{5}{|c|}{ Temperature } \\
\hline & $\mathbf{1}$ & $\mathbf{2}$ & $\mathbf{3}$ & $\mathbf{4}$ & $\mathbf{5}$ \\
\hline Total No. & & & $\mathbf{2 8}$ & $\mathbf{5 0}$ & $\mathbf{2 3}$ \\
\hline
\end{tabular}

\subsection{Discussion}

Flavor. nDalem Prince Joyokusuman (Gadri Resto) serves a variety of traditional and Western foods and drinks, such as Nasi Blawong, Nasi Gurih, Salad Jawa, Beef Cordon Blue, Spaghetti, Gajah Dekem, Prawan Kenes, Bir Jawa, Wedang Secang, and Stup Jambu. The food, snacks, and beverages served at nDalem Prince Joyokusuman (Gadri Resto) generally are the King/Sultan Hamengkubuwono XII to Hamengkubuwono X's favorite menu. In producing the food, snacks and beverages, the chef and cooks must pay attention to the cooking methods such as moist heat, dry heat, and fat method. Those food processing term (sauté) must be well understood by chefs or cooks. It is important because as the chef is sauteing the ground spices such as garlic, shallot, candle nut, coriander, galangal, salam leaf, and etc., it can produce a tasty flavor and the taste itself can be more dominant. Chef and cook nDalem Prince Joyokusuman (Gadri Resto) has used the cooking method to process all the food, snacks and drinks for its consumers.

Color. In making a food, a cook or chef must understand correctly what they are doing in the kitchen. Food processing requires techniques so that the food has the perfect color combination. If in the process of cooking a chef or cook makes a mistake, cooking exceeds the specified time limit for instance, it will affect its color combination as it has the probability to produce colors that are not as good as it is expected to have. For example, scorched colors will appear if the cooked food is not stirred perfectly.

Taste. The taste of food is a very determinant of food quality. This must be understood by the restaurant owner and all employees. The taste of good and delicious food will certainly make the restaurant get consumer trust. A chef must have standards in food and beverage processing. It is better known as standard recipes. These standard recipes will be used by all chef of the restaurant to maintain the taste of food and beverages. With standard recipes made by chefs and restaurant owners, restaurants will be able to retain the taste of the food they are serving.

Texture. Not only the taste and flavor that affects the quality of food. Food texture is also an important component in determining food quality. Food texture such as soft, not fibrous, and not chewy are not expected to occur when the food is being produced/cooked. Food texture is greatly influenced by the knowledge and experience of the chef and the cook. Knowledge of a chef and cook makes processed food can be eaten and digested well by consumers. In cooking rice for instance, the composition of water and rice must be balanced. If it is not balanced then the rice will be so dry/not yet perfectly cooked. It also happens in cooking meat for steak. If it is cooked in a long time, it will bring out its chewiness. On the contrary, if the meat is so thin and it is cooked in a long time (stew), it will change the texture of the meat to be softer than it is expected. Chef and cook nDalem Prince Joyokusuman (Gadri Resto) understand the texture of good food. The collaboration between the restaurant owner and chef makes the food served in the restaurant has a nice texture to eat.

Temperature. Food ordered by consumers is expected to always be warm to maintain its quality. Food temperature greatly affects the aroma, taste, and texture of the food itself. When the food is cold the texture of the food will be hard and chewy and the aroma will no longer be pleasant. When consumers order the food, the waiter will record their order towards 
their captain order and it will then be forwarded to the kitchen. In the kitchen chef and cook will cook food according to consumer orders based on the captain order. A chef must be able to give direction to his cook whichever is the first menu enters the kitchen then this menu will be cooked as soon as possible. Such a system is expected to maintain food temperatures until the waiter serves the food on the table.

\section{Conclusion}

Consumer response towards nDalem Prince Joyokusuman (Gadri Resto)'s food quality is considered good on scale of 4. It provides that nDalem Prince Joyokusuman's food quality, seen from 5 dimensions; flavor, color, taste, texture, and temperature, is able to make its consumer to get satisfied. This restaurant's food quality is established because it has wellorganized collaboration between the owner, chef, and cook who try to maintain the restaurant's standard recipe. Moreover, the chef and cook's knowledge in cooking technique and managing time are very helpful to the restaurant in making food which has enjoyable, delicious, and satisfying flavor, color, texture, taste, and temperature.

\section{References}

[1] S. P. Nugroho, "Kualitas Pelayanan Gadri Resto: Respon Konsumen Sebagai Pendekatan Penelitian," Jurnal Nasional Pariwisata., vol. 6, no. 1, pp. 26-35. 2014.

[2] D. R. Soriano, "Customer's expectations factors in restaurants: The situation in Spain," International Journal Quality and Reliability Management., vol. 19, no. 8, pp. 1055-1067. 2002.

[3] H. Qin., V. R. Prybutok., and Q. Zhao. "Perceived service quality in fast-food restaurants: Empirical evidence from China", International Journal o of Quality and Reliability Management., Vol. 27, No.4, pp.424-437. 2009.

[4] Y. Namkung., \& S. S. C. Jang. "Does food quality really matter in restaurants? Its impact on customer satisfaction and behavioral intention", Journal of Hospitality \& Tourism Research, pp. 387-410. 2007.

[5] F. Tjiptono., \& G. Chandra. Service, Quality and Satisfaction, ed 3. Yogyakarta: Andi, 2011.

[6] J. S. Nugroho. Perilaku Konsumen: Cetakan Kedua. Jakarta: Prenada Media. 2005.

[7] Sugiyono. Metode Penelitian Kuantitatif, Kualitatif dan R\&D. Bandung: Alfabeta. 2011. 